\title{
THE ROLE OF APPARENT DIFFUSION COEFFICIENT VALUE IN DIFFERENTIATING BENIGN FROM MALIGNANT SOFT TISSUE MASSES
}

\author{
Tara Farooq Kareem', Sanaa Jawad Kadhim², Manwar Al-Naqqash³ \\ 1 - Radiology Department, Oncology Teaching Hospital, Baghdad Medical City Complex. \\ 2 - Al-Mahmoudia General Hospital, Baghdad Al-Karkh Health Directorate. \\ 3 - Department of Surgery, College of Medicine, University of Baghdad. Baghdad, Iraq.
}

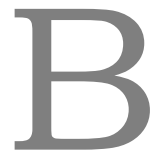

ackground. Soft tissue masses are frequently referred for imaging assessment. Magnetic resonance imaging (MRI) is the technique of choice for detection of these masses and local staging of the malignant one.

Purpose. The study is aimed to measure the apparent diffusion coefficient (ADC) values of different soft tissue masses and determine the cut-off value that can be helpful in differentiating between the benign and malignant histological types.

Materials and methods. A prospective study was conducted in the Radiology Department of the Oncology Teaching Hospital. A total of 37 cases enrolled during the period from 12th July 2019 to 20th February 2020. Diffusion weighted images (DWI) were performed for all cases. The mean ADC value for the enhancing component of each mass was measured on the generated ADC map done at high b-value of $800 \mathrm{sec} / \mathrm{mm} 2$.

Results. The benign soft tissue masses were recorded in 15 (40.5\%), while malignant masses found in $22(59.5 \%)$ of patients. The greatest ADC values (mean $\pm \mathrm{SD}$ ) measured for the benign masses was $(1.97 \times 10-3 \mathrm{~mm} 2 / \mathrm{s} \pm 0.39)$ for hemangiomas. While the greatest ADC value results for the malignant masses was for myxoid liposarcoma $(2.11 \times 10-3 \mathrm{~mm} 2 / \mathrm{s} \pm 0.45)$. The lowest ADC values were observed in hematological tumors. In a selected group of masses which their enhancing componenet expressed low signal or intermediate hyperintense signal in T2-WI $(n=26)$, the mean ADC value for the malignant masses $(n=18)$ was lower than the mean ADC value of benign $(n=8)(0.863 \pm 0.28$ vs. $1.675 \pm 0.39$ ), with statistically significant association (P-value $=0.002)$ and the ADC cut-off value of $1.42 \times 10-3 \mathrm{~mm} 2 / \mathrm{s}$ gives a high sensitivity of $94.44 \%$, a high specificity of $87.5 \%$, and accuracy of $92.31 \%$ for differentiating malignant from benign masses which was statistically significant (P-value $<0.000)$.

Conclusions. In a selected group of soft tissue masses which their enhancing componenet express low or intermediate hyperintense signal in T2-WI, the mean ADC value was lower in malignant soft tissue masses than that in benign masses with a cut off value of $1.42 \times 10-3 \mathrm{~mm} 2 / \mathrm{s}$ gives a high sensitivity and a high specificity.

Keywords: soft tissue masses, MRI-DWI, ADC values.

Corresponding author: Manwar Al-Naqqash, e-mail: abudallaham@gmail.com

For citation: Tara Farooq Kareem, Sanaa Jawad Kadhim, Manwar Al-Naqqash. The role of apparent diffusion coefficient value in differentiating benign from malignant soft tissue masses. REJR 2021; 11(3):138-150. DOI: 10.21569/2222-7415-2021-11-3-138-150.
Received:
02.04.21
Accepted:
30.08 .21 


\title{
РОАЬ ИЗМЕРЯЕМОГО КОЭФФИЦИЕНТА АИФФУЗИИ В АИФФЕРЕНЦИАЛЬНОЙ АИАГНОСТИКЕ АОБРОКАЧЕСТВЕННЫХ И ЗАОКАЧЕСТВЕННЫХ ОБРАЗОВАНИЙ МЯГКИХ ТКАНЕЙ
}

\author{
Тара Фарук Карим', Сана Ажавал КаАхим², Манвар ан-Наккаш³ \\ 1 - Отделение мучевой диагностики, Онкологическая больница, Медицинский Городской Комплекс Багдада. \\ 2 - ГАавный госпиталь Al-Mahmoudia, Управление здравоохранения Багдада А^ь-Карха. \\ 3 - Хирургическое отдемение Медицинского комеджа Багдадского университета. Багдад, Ирак.
}

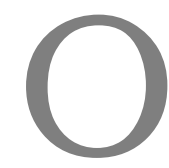

бразования мягких тканей часто обследуют с применением методов мучевой диагностики. Магнитно-резонансная томография (MRI) явцяется методом выбора дмя выявмения образований мягких тканей и мокального опредемения стадии зцокачественного процесса.

Цель исследования. Определение значений измеряемого коэффициента диффузии (ADC) различных образований мягких тканей и определение порогового значения, которое может быть полезно при дифференциальной диагностике доброкачественных и змокачественных гистологических типов.

Материалы и методы. Проспективное исследование бымо проведено в отдемении мучевой диагностики онкологической больницы. Всего за период с 12 июля 2019 г. по 20 февраля 2020 г. было зарегистрировано 37 пациентов. Дия всех случаев были выполнены диффузновзвешенные изображения. Среднее значение ADC для контрастного компонента каждого образования было измерено на сгенерированной карте ADC, выполненной при высоком значении bvalue $800 \mathrm{c} / \mathrm{mm} 2$.

Результаты. Доброкачественные образования мягких тканей были зарегистрированы у 15 (40,5\%), змокачественные - у 22 (59,5\%) пациентов. Наибольшие значения ADC (среднее \pm стандартное отклонение), измеренные дмя доброкачественных образований, составили $(1,97 \times 10-$ 3 мм2/с $\pm 0,39)$ для гемангиом. В то время как самые высокие результаты значения ADC для змокачественных образований были для миксоидной мипосаркомы $(2,11 \times 10-3$ мм2/с $\pm 0,45)$. Самые низкие значения ADC наблюдались в гематологических опухолях. В выбранной группе опухолей, контрастный компонент которых выражает низкий сигнал или промежуточный гиперинтенсивный сигнал в T2-WI ( $\mathrm{n}=26)$, среднее значение $\mathrm{ADC}$ для злокачественных образований $(\mathrm{n}=18)$ было ниже, чем среднее значение $\mathrm{ADC}$ для доброкачественных $(\mathrm{n}=8)(0,863 \pm 0,28$ против $1,675 \pm 0,39$ ), со статистически значимой зависимостью (значение $\mathrm{P}=0,002$ ) и пороговым значением ADC 1,42х10-3 мм2/с, дает высокую чувствительность 94,44\%, высокую специфичность $87,5 \%$ и точность $92,31 \%$ дмя дифференциации змокачественных образований от доброкачественных, что бымо статистически значимым (значение $\mathrm{P}<0,000$ ).

Выводы. В выбранной группе образований мягких тканей, контрастный компонент которых выражает низкий или промежуточный гиперинтенсивный сигнал в T2-WI, среднее значение ADC было ниже в змокачественных образованиях мягких тканей, чем в доброкачественных образованиях с пороговым значением 1,42х10-3 мм2/s, дает высокую чувствительность и высокую специфичность.

Кıючевые слова: образования мягких тканей, MRI-DWI, значения ADC.

Контактный автор: Манвар А^ь-Наккаш, e-mail: abudallaham@gmail.com

Для иитирования: Тара Фарук Карим, Сана Джавад Кадхим, Манвар ан-Наккаш. Роль измеряемого коэфрфииента дифрузии в дифреренииальной диагностике доброкачественных $и$ злокачественных образований мягких тканей. REJR 2021; 11(3):138-150. DOI: 10.21569/22227415-2021-11-3-138-150.
Статья получена:
02.04.21
Статья принята:
30.08.21 


\section{RUSSIAN ELECTRONIC JOURNAL OF RADIOLOGY}

\section{I} ntroduction.

Soft tissue tumours may be benign, malignant or non-neoplastic [1]. MRI is the technique of choice for local staging of a soft tissue masses, especially if it is in a deep location where ultrasonography unable to assess masses extent and relations. It is sensitive, can be tissue-specific and allow assessment of most masses [2]. MR imaging is well suited the staging, preoperative planning, postsurgical evaluation, and post-therapy surveillance of soft tissue masses [3].

DWI is an MR technique that is sensitive to the random motion of water. Enhancement identifies areas of inflammatory post-surgical change as well as recurrence of disease [4].

The diffusion constant in biological tissues can be measured by repeated scanning with different $b$ values but identical parameters, in particular unchanged gradient direction. Observed diffusion constants are indicated like Apparent Diffusion Coefficents (ADCs) to differentiate them from the constant of unrestricted diffusion in pure water [4]. Using ADCs the so called ADC maps can be built: a grey scale represents the mean ADC of the corresponding voxel. It is important to note that an area of viable tumor bright on a DWI image will be dark on the corresponding ADC map $[5,6]$. Diffusion of water is in fact more restricted in tumors than in normal tissues and this on DWI is seen as a high signal intensity in viable tumors. DWI and ADC maps provide qualitative and quantitative information about tissue cellularity and cell integrity. Potentially this is helpful in identifying not only benign from malignant lesions but also in revealing necrotic tumors and peri tumoral edemas from residual viable tumors underscoring the efficacy of tumor response to therapy [4, 7-9].

\section{Materials and methods.}

Study design and setting.

A comparison study was conducted in the Radiology Department of the Oncology Teaching Hospital. A total 37 soft tissue masses were studied. The study sample consisted of 12 male and 25 female.

\section{Exclusion Criteria.}

We excluded patients with masses that showed no enhancement (as lipomas and a case of an intramuscular hydatid cyst) or just smooth enhancing rim with no obvious enhancing solid component (as cases of hematoma and abscesses), (as the ADC value used in our research was measured for the enhancing solid component), and pediatrics age groups.

\section{MRI protocols.}

MRI examination was performed utilizing the 1.5 Tesla Siemens system (Magnetom Aera; Siemens Healthineers, Erlangen, Germany). The protocol applied in our examined patients includ- ed the routine sequences for studying soft tissue masses [T1-WI, T2-WI and T2-fat suppression, T1fat suppression following IV contrast injection (gadolinium) at a dose of $0.1 \mathrm{mmol} / \mathrm{kg}$. axial and sagittal/or coronal images were taken according to the site of the mass.

Diffusion weighted images (DWI) were performed for all the included cases before giving IV contrast using single shot echo planer imaging sequence EPI in axial plane. The parameters were: $\mathrm{TR}=5580 \mathrm{~ms}, \mathrm{TE}=75 \mathrm{~ms}$, slice thickness $=4 \mathrm{~mm}, \mathrm{~b}$ values $(50,400$, and $800 \mathrm{~s} / \mathrm{mm} 2)$. All diffusion images and conventional images were obtained at the same slice locations.

\section{ADC measurement.}

The mean ADC value for the enhancing component of each soft tissue mass was measured on the generated ADC map done at high b-value of $800 \mathrm{~mm} / \mathrm{sec} 2$. The ADC value was measured by applying region of interest (ROI) on the solid part of the tumor avoiding any area of necrotic, cystic or hemorrhagic changes and encircling in the most prominent restrictive diffusion (most hypo intense area seen in the diffusion weighted image). Three ROIs were applied for each tumor (the average area of each ROI was about $0.50-1 \mathrm{~cm} 2$ as circular area) and the mean of the ADC values was calculated.

\section{Ethical considerations.}

Written informed consent was obtained from the patients for participating in this study. The study conforms to the 1995 Helsinki declaration and was approved by The Medical Ethical Committee of College of Medicine/Baghdad University.

Statistical analysis.

Statistical package for social science (SPSS statistics for windows, version 11.0, Chicago: SPSS, Inc.) software version 20 was used. Results were described in the form of frequencies and percentage distribution for qualitative data and (mean, SE of mean and standard deviation) calculation for quantitative data. Paired samples T test was used to estimated differences in quantitative variables. The area under a receiver operating characteristic (ROC) curve and identify a cut off value to diagnose malignancy was used to evaluated the diagnostic performance of DW-MRI against the pathology findings. Based on the cut off value, a $2 \times 2$ contingency table was constructed and the sensitivity, specificity, PPV, NPP, likelihood ratios and Youden's index. A one-sided $\mathrm{P}$ value of 0.05 or less was considered statistically significant.

\section{Results.}

General demographic and Soft tissue masses.

The most commonly recorded age group was that between $21-30$ and $51-60$ years as $8(21.6 \%)$. The mean age was $38.39 \pm 16.59$ years. Regarding 


\section{RUSSIAN ELECTRONIC JOURNAL OF RADIOLOGY}

\begin{tabular}{|c|c|c|c|}
\hline \multicolumn{2}{|c|}{ Characteristics } & No. & $\%$ \\
\hline \multirow[t]{6}{*}{ Age (years) } & $11-20$ & 7 & 18.9 \\
\hline & $21-30$ & 8 & 21.6 \\
\hline & $31-40$ & 5 & 13.5 \\
\hline & $41-50$ & 7 & 18.9 \\
\hline & $51-60$ & 8 & 21.6 \\
\hline & $>60$ & 2 & 5.4 \\
\hline \multirow[t]{2}{*}{ Gender } & $M$ & 12 & 32.4 \\
\hline & $\mathrm{F}$ & 25 & 67.6 \\
\hline \multirow[t]{4}{*}{ Sites } & Trunk & 7 & 18.9 \\
\hline & Head and neck & 7 & 18.9 \\
\hline & Lower limbs & 20 & 54 \\
\hline & Upper limbs & 3 & 8.1 \\
\hline \multirow[t]{2}{*}{ Sizes } & $<5 \mathrm{~cm}$ & 8 & 21.6 \\
\hline & $\geq 5 \mathrm{~cm}$ & 29 & 78.4 \\
\hline \multirow[t]{2}{*}{ Types } & Benign & 15 & 40.5 \\
\hline & Malignant & 22 & 59.5 \\
\hline
\end{tabular}

gender, $12(32.4 \%)$ were male, and $25(67.6 \%)$ of patients were female (Table 1).

The majority was on the lower limbs as 20 (54\%). Those with tumor mass size below $5 \mathrm{~cm}$ were $8(21.6 \%)$. The mean mass size was $10.2 \pm 6.43 \mathrm{~cm}$, with median size reached to 8.8 $\mathrm{cm}$. The smallest tumor was $2.2 \mathrm{~cm}$, while the largest size was $30 \mathrm{~cm}$. Benign STTs were detected in $15(40.5 \%)$ patients, while malignant tumors were found in $22(59.5 \%)$ of patients (Table 1) (Fig. $1)$.

Apparent diffusion coefficient (ADC) values.

The ADC values (mean $\pm \mathrm{SD}$ ) for the 15 benign soft tissue masses were: $(1.97 \times 10-3 \mathrm{~mm} 2 / \mathrm{s}$ \pm 0.39 ) for six cases of hemangiomas which was the greatest ADC value measured, $(1.62 \times 10-3$ $\mathrm{mm} 2 / \mathrm{s} \pm 0.256$ ) for five cases of benign neurogenic tumors (no myxoid component), (1.54 x10-3 $\mathrm{mm} 2 / \mathrm{s} \pm 0.014)$ for two cases of fibromatosis, (2.4 $\mathrm{x} 10-3 \mathrm{~mm} 2 / \mathrm{s}$ ) for one case of intramuscular myxoma and $(2.2 \times 10-3 \mathrm{~mm} 2 / \mathrm{s})$ for myxoid neurofibroma, as shown in Table 2 (Fig. 2).

The ADC value results (mean $\pm \mathrm{SD}$ ) for the 22 malignant masses were as followed: four masses of myxoid liposarcoma ( $2.11 \times 10-3 \mathrm{~mm} 2 / \mathrm{s} \pm 0.45)$, three masses of malignant peripheral nerve sheath tumor $(1.23 \times 10-3 \mathrm{~mm} 2 / \mathrm{s} \pm 0.26)$, and two masses for each of Ewing sarcoma (0.87 x10-3 $\mathrm{mm} 2 / \mathrm{s} \pm 0.007)$, pleomorphic sarcoma (0.97 x10-3 $\mathrm{mm} 2 / \mathrm{s} \pm 0.15)$ and NHL $(0.545 \times 10-3 \mathrm{~mm} 2 / \mathrm{s}$ \pm 0.035 ). As a results, the lowest $\mathrm{ADC}$ values were observed in hematological tumors (two cases of NHL, one case of extramedullary plasmacytoma and one case of myeloid sarcoma), whereas the greatest ADC values were observed in malignant liposarcomas, as shown in Table 2 (Fig. 3).

Generally, the mean of ADC value was higher in benign soft tissue masses than that in malignant masses $(1.84 \pm 0.37$ vs. $1.09 \pm 0.58)$ and it was strongly statistically significant difference (Pvalue $<0.000$ ), as shown in Table 3 (Fig. 4).

In particular, we subdivided the masses into two groups according to the signal intensity of the enhancing components in T2-WI into:

a. Very hyperintense signal in T2-WI $(11 / 37)$ which were either tumors of myxoid component ((4/11) myxoid liposarcomas, and (1/11) benign intramuscular myxoma) or hemangiomas (6/11).

b. Hypointense signal and intermediate hyperintense signal in T2-WI (26/37 cases).

In this study, the mean ADC value for the malignant masses with the very hyperintense signal of the enhancing part in T2-WI $(n=4)$ was higher than mean of benign $(n=7),(2.11 \pm 0.45$ vs. $2.03 \pm 0.39$ ), with no significant association ( $\mathrm{P}$ value $=0.49$ ). However, the mean $\mathrm{ADC}$ value for the malignant masses which their enhancing part showed hypointense or intermediately hyperintense signal in T2-WI $(\mathrm{n}=18)$ was lower than the mean of benign $(n=8)(0.863 \pm 0.28$ vs. $1.675 \pm 0.39)$, with statistically significant association $(\mathrm{P}-$ value $=0.002$ ), as shown in Table 4 .

The ADC value accuracy in the diagnosis of soft tissue masses.

The diagnostic achievement of DW-MRI versus the pathology results was determined by using the area under a receiver operating characteristic (ROC) curve to the identify a cut off value for $\mathrm{ADC}$ to differentiate malignant from benign soft tissue masses. In DW-MRI images, the ADC cut 


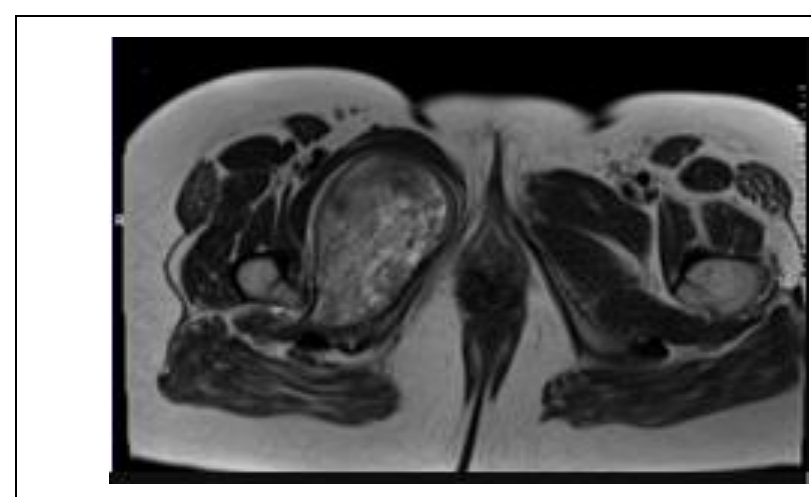

Fig. 1 a (Рис. 1 a)

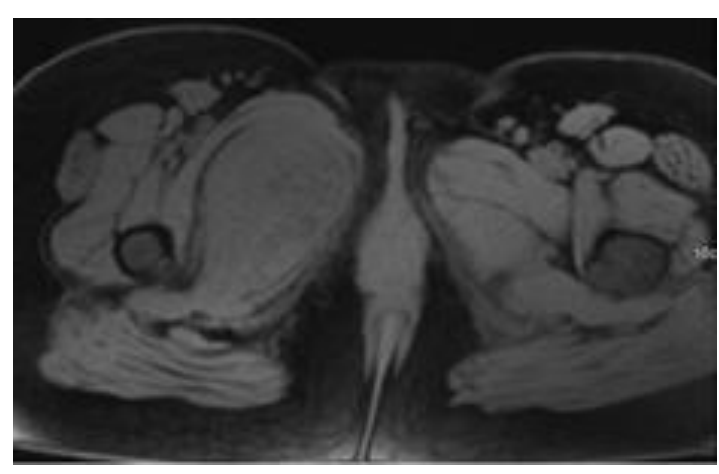

Fig. 1 с (Puc. 1 в)

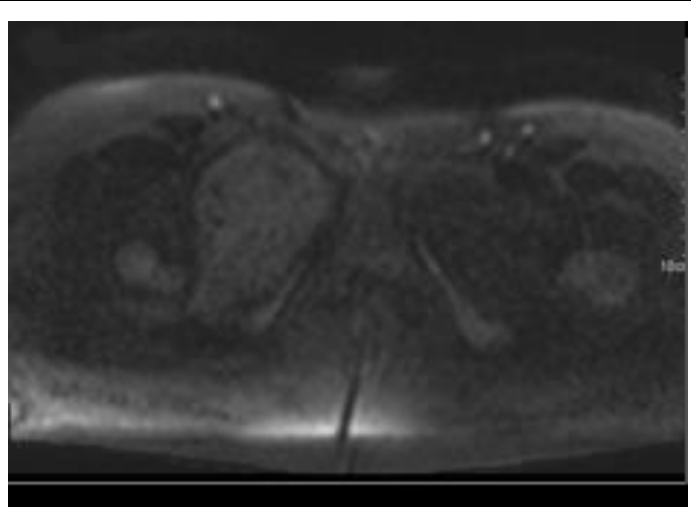

Fig. 1 e (Рис. 1 А)

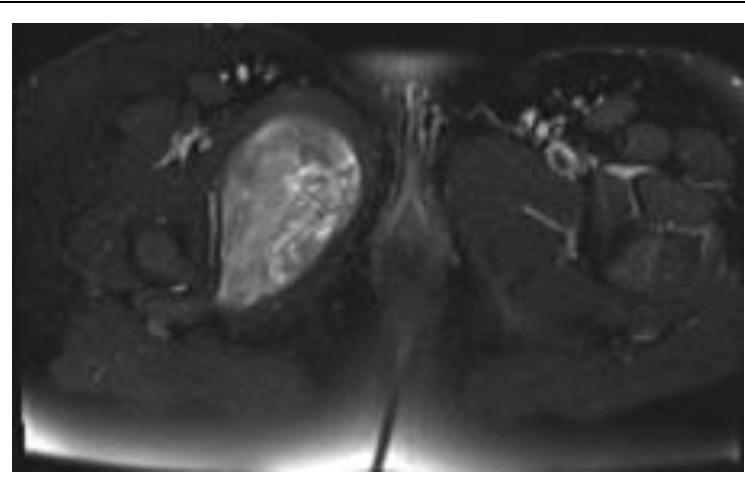

Fig. 1 b (Рис. 1 б)

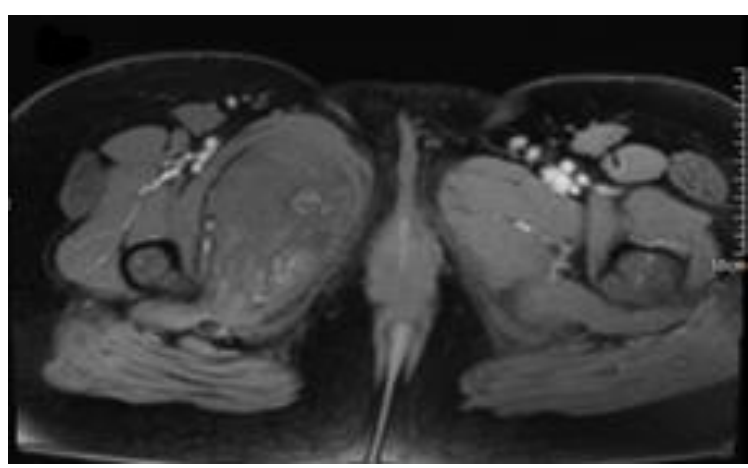

Fig. 1 d (Рис. 1 г)

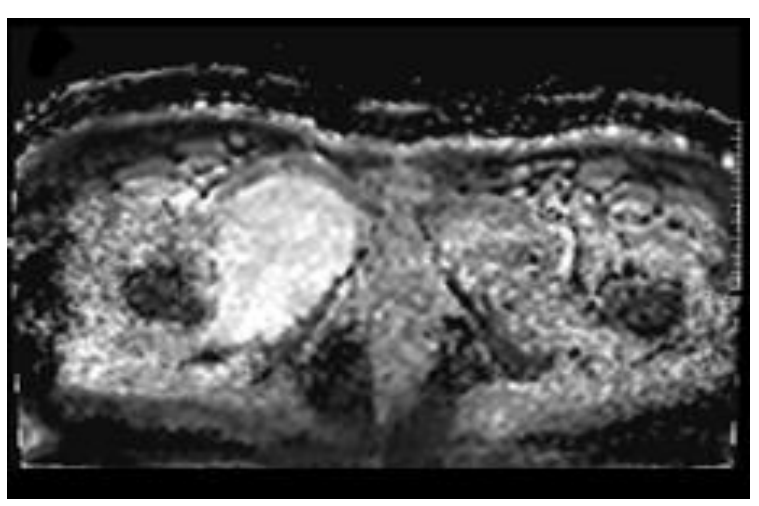

Fig. $1 \mathrm{f}$ (Рис. 1 e)

Fig. 1. MRI, transverse view. $a-T 2-W I, b-T 2$ fat suppression, $c, d-T 1$ fat suppression before and after IV contrast, e-DWI at $800, b, f-A D C$.

A case of benign neurofibroma. Axial MRI images revealed a deep soft tissue mass at the Rt thigh with fat split sign with the ADC value measured $(2.2 \times 10-3 \mathrm{~mm} 2 / \mathrm{sec})$.

Рис. 1. МРТ, аксиальная плоскость. а - Т2-ВИ, б - Т2 с поАавлением сигнала от жира, в, г - Т1 с поАавлением сигнала от жира Ао и после внутривенного контрастирования, А - DWI при 800, б, е $-A D C$.

Доброкачественная нейрофиброма. Аксиальные МРТ-изображения выявили глубокую массу мягких тканей в области правого бедра со знаком расщепления жира с измеренным значением ADC (2,2 х 10-3 мм2 / сек). 


\begin{tabular}{|c|c|c|}
\hline \multicolumn{3}{|c|}{ Table №2. $\quad$ ADC values for Benign $(n=15)$ and Malignant $(n=22)$ STTs. } \\
\hline STTs & & $\begin{array}{l}A D C\left(\times 10^{-3} \mathrm{~mm}^{2} / \mathrm{s}\right) \\
\text { mean } \pm S D\end{array}$ \\
\hline \multirow{5}{*}{$\begin{array}{l}\text { Benign } \\
(n=15)\end{array}$} & Hemangioma $(n=6)$ & $1.97 \pm 0.39$ \\
\hline & Benign neurogenic tumors (no myxoid component) $(n=5)$ & $1.62 \pm 0.256$ \\
\hline & Fibromatosis $(\mathrm{n}=2)$ & $1.54 \pm 0.014$ \\
\hline & Intramuscular myxoma & 2.4 \\
\hline & Myxoid neurofibroma & 2.2 \\
\hline \multirow{14}{*}{$\begin{array}{l}\text { Malignant } \\
(n=22)\end{array}$} & Ewing sarcoma $(n=2)$ & $0.865 \pm 0.007$ \\
\hline & $\mathrm{NHL}(\mathrm{n}=2)$ & $0.55 \pm 000$ \\
\hline & Myxoid liposarcoma $(n=4)$ & $2.11 \pm 0.45$ \\
\hline & Malignant peripheral nerve sheath tumor $(n=3)$ & $1.23 \pm 0.26$ \\
\hline & Pleomorphic sarcoma $(n=2)$ & $0.965 \pm 0.15$ \\
\hline & Malignant fibrous histiocytoma & 0.78 \\
\hline & Myeloid sarcoma & 0.48 \\
\hline & Extra axial osteogenic sarcoma & 0.76 \\
\hline & Lieomyosarcoma & 0.75 \\
\hline & Extramedullary plasmacytoma & 0.54 \\
\hline & Liposarcoma(non myxoid type ) & 1.35 \\
\hline & Dermatofibrosarcoma protuberance & 0.92 \\
\hline & Fibrosarcoma & 0.84 \\
\hline & Metastatic adenocarcinoma & 0.68 \\
\hline
\end{tabular}

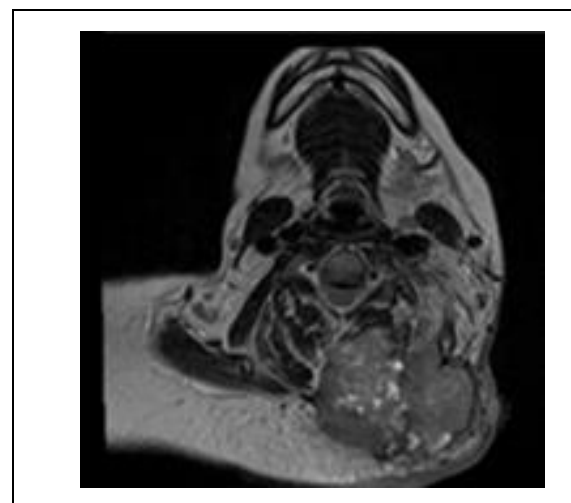

Fig. 2 a (Рис. 2 a)

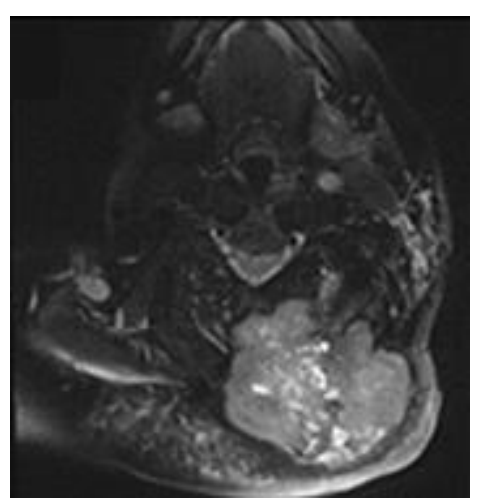

Fig. 2 d (Рис. 2 г)

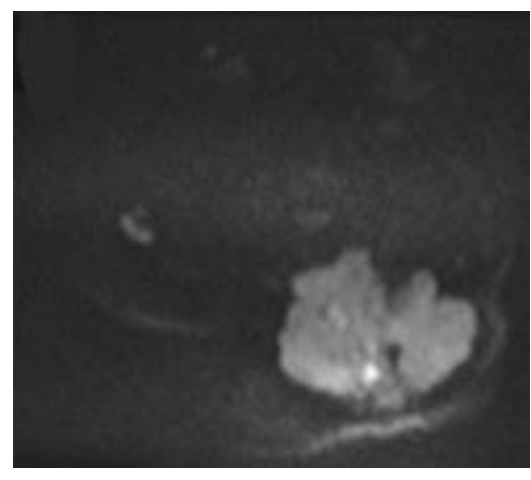

Fig. 2 b (Рис. 2 б)

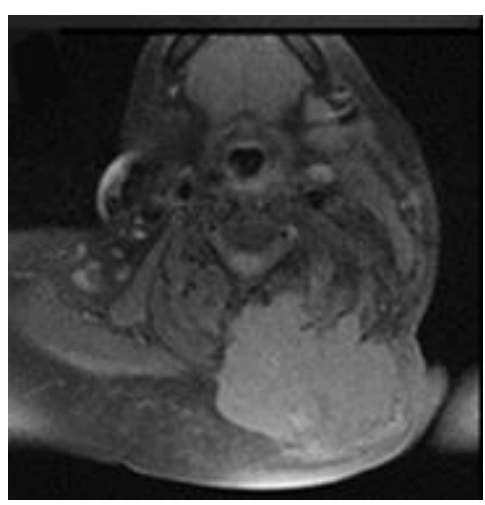

Fig. 2 e (Рис. 2 A)

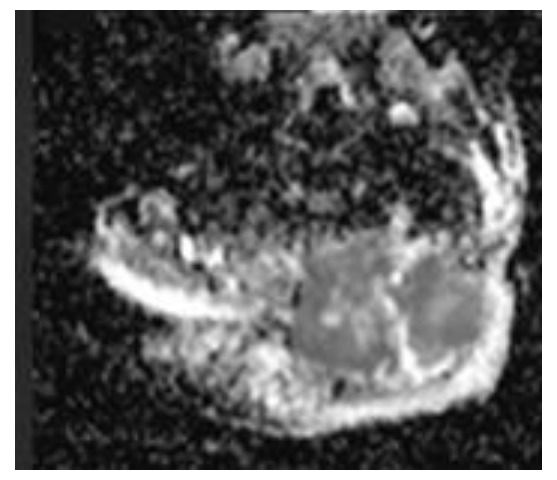

Fig. 2 с (Pис. 2 в)

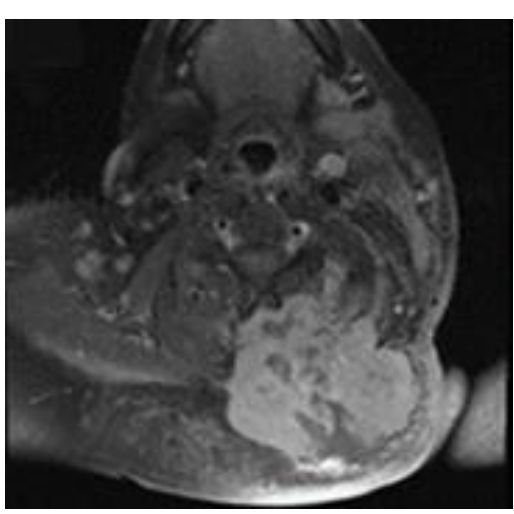

Fig. 2 f (Puc. 2 e) 
Fig. 2. MRI, transverse view. $a-T 2-W I, b-D W I$ at $800, b, c-A D C, d-T 2$ fat suppression, e - T1 fat suppression pre contrast, $\mathrm{f}-\mathrm{Tl}$ fat suppression post contrast.

A case of histopathologically proven soft tissue Ewing sarcoma. Axial MRI images revealed a deep soft tissue mass invading the Lt paraspinal muscles, with the enhancing compoennet express intermediate hyperintense signal in T2-WI and shows restricted diffusion with the ADC value measured $(0.78 \times 10-3 \mathrm{~mm} 2 / \mathrm{sec})$.

Рис. 2. МРТ, аксиальная плоскость. а - Т2-ВИ, 6 - DWI при 800, б, в - ADC, г - Т2 с поАавлением сигнала от жира, А - Т1 с поАавлением сигнала от жира Ао внутривенного контрастирования, е T1 с поАавлением сигнала от жира после внутривенного контрастирования.

Случай гистопатологически подтвержденной саркомы Юинга мягких тканей. Аксиальные изображения МРТ выявили образование мягких тканей, глубоко проникающее в параспинальные мышцы Lt, при этом контрастный компонент выражает промежуточный гиперинтенсивный сигнал в T2-WI и показывает ограниченную дифффузию с измеренным значением $\mathrm{ADC}(0,78 \times 10-3$ мм2 сек).

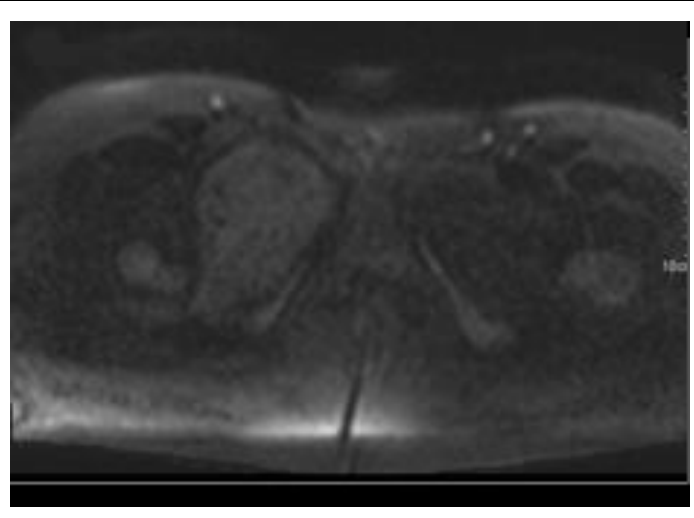

Fig. 3 a (Pис. 3 a)

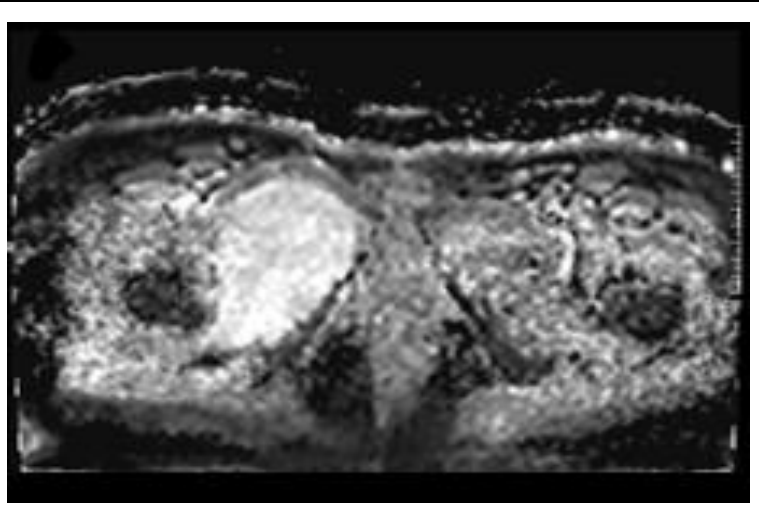

Fig. 3 b (Рис. 3 б)

Fig. 3. MRI, axial view, leg. a - DWI, b-ADC map.

A case of extra-medullary plasmacytoma. Examination revealed a deep soft tissue mass within the calf muscle with restricted diffusion and $\mathrm{ADC}$ value of $(0.54 \mathrm{x} 10-3 \mathrm{~mm} 2 / \mathrm{sec})$.

Рис. 3. МРT, аксиальная плоскость, нога. а - DWI, 6 - ADC карта.

Случай экстрамедумяярной плазмоцитомы. Обследование выявимо образование мягких тканей, глубоко проникающие в икроножную мышцу с ограниченной диффузией и значением ADC (0,54x10-3 мм2/сек).

Table №3. ADC values analysis between Malignant and Benign soft tissue masses (n=37).

\begin{tabular}{l} 
Findings \\
\hline ADC values \\
$\left(\times 10^{-3} \mathrm{~mm}^{2} / \mathrm{s}\right)$
\end{tabular}

$\left(\times 10^{-3} \mathrm{~mm}^{2} / \mathrm{s}\right)$

\begin{tabular}{|c|c|c|c|}
\hline \multicolumn{2}{|l|}{ Findings } & Malignant $(n=22)$ & Benign $(n=15)$ \\
\hline & & \multicolumn{2}{|l|}{ No. (\%) } \\
\hline \multirow{5}{*}{$\begin{array}{l}\text { ADC values } \\
\left(\times 10^{-3} \mathrm{~mm}^{2} / \mathrm{s}\right)\end{array}$} & $0-0.5$ & $1(4.5)$ & 0 \\
\hline & $0.51-1$ & $13(58.5)$ & 0 \\
\hline & 1.1-1.5 & $5(22.5)$ & $4(26.7)$ \\
\hline & $1.51-2$ & 0 & $8(53.3)$ \\
\hline & $2.1-2.5$ & $3(13.5)$ & $3(20)$ \\
\hline \multicolumn{2}{|l|}{ Mean \pm SD } & $1.09 \pm 0.58$ & $1.84 \pm 0.37$ \\
\hline \multicolumn{2}{|l|}{ Median } & 0.86 & 1.8 \\
\hline \multicolumn{2}{|l|}{ Minimum } & 0.48 & 1.3 \\
\hline \multicolumn{2}{|l|}{ Maximum } & 2.48 & 2.45 \\
\hline \multicolumn{2}{|l|}{ SE of mean } & 0.124 & 0.097 \\
\hline
\end{tabular}




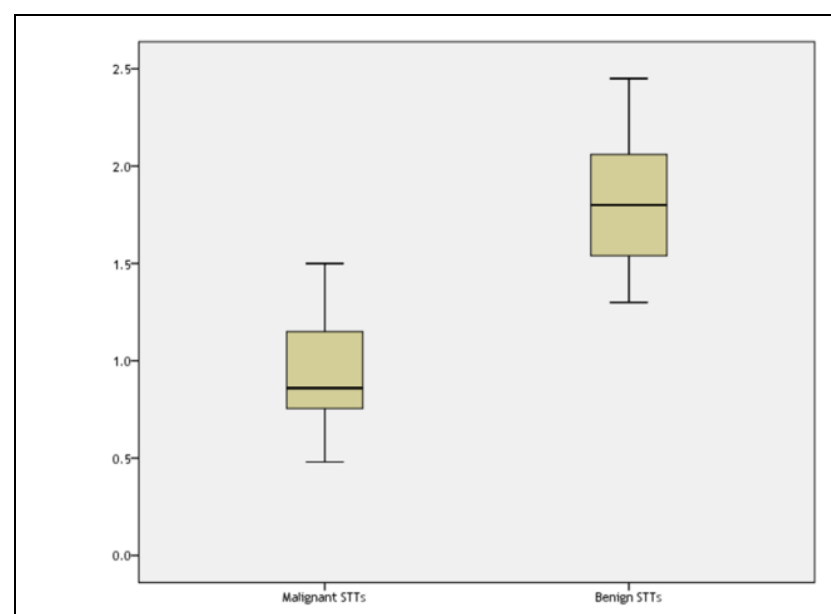

Fig. 4 (Рис. 4)

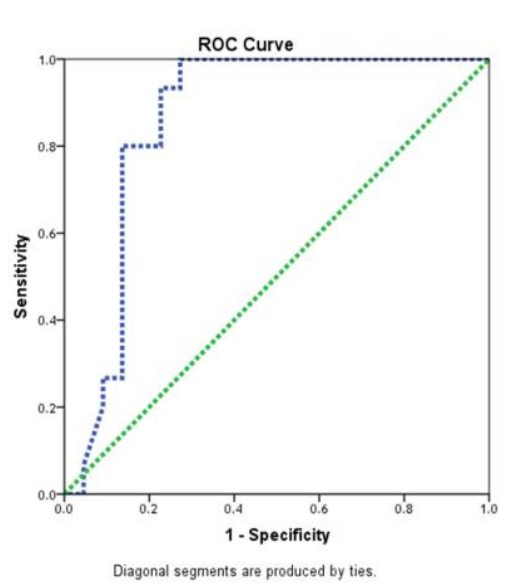

Fig. 5 (Рис. 5)

\section{Fig. 4. Diagram.}

Box plot of ADC values for malignant and benign STTs of the study.

\section{Рис. 4. Схема.}

Ящичная диаграмма значений ADC дмя змокачественных и доброкачественных STTs в исследовании.

\section{Fig. 5. Diagram.}

ROC curve for the ADC values of soft tissue tumors to predict malignant masses.

\section{Рис. 5. Схема.}

Кривая ROC для значений $\mathrm{ADC}$ опухолей мягких тканей дмя прогнозирования змокачественных образований.

Table №4. ADC values (x10-3mm2/s) analysis between malignant (n=22) and benign $(n=15)$ soft tissue masses according to the signal intensities of the enhancing solid component in T2-WI.

\begin{tabular}{l|l|l|l|}
$\begin{array}{l}\text { MRI T2-W1 signals intensity } \\
\text { of the enhancing component }\end{array}$ & $\begin{array}{l}\text { ADC of Malignant } \\
\text { mean } \pm \text { SD } \\
\text { (Cut off value) }\end{array}$ & $\begin{array}{l}\text { ADC of Benign } \\
\text { mean } \pm \text { SD }\end{array}$ & $P$-value* \\
\hline $\begin{array}{l}\text { Very hyperintense } \\
(n=4+7)\end{array}$ & $\begin{array}{l}2.11 \pm 0.45 \\
(3.01)\end{array}$ & $2.03 \pm 0.39$ & $0.784(0.49)$ \\
\hline $\begin{array}{l}\text { Intermediate hyperintense } \\
(n=18+8)\end{array}$ & $\begin{array}{l}0.863 \pm 0.28 \\
(1.423)\end{array}$ & $1.675 \pm 0.39$ & $-4.83(0.002)$ \\
\hline
\end{tabular}

*Paired T test

Table №5. Diagnostic MRI accuracy regarding the ADC values in ST masses regardless the signal intensity of the enhancing components in T2WI.

\begin{tabular}{|c|c|c|c|}
\hline \multirow{2}{*}{\multicolumn{2}{|c|}{ Findings }} & Malignant (n=22) & Benign $(n=15)$ \\
\hline & & \multicolumn{2}{|l|}{ No. } \\
\hline \multirow{2}{*}{$\begin{array}{l}\text { ADC cut off values } \\
\left(\times 10^{-3} \mathrm{~mm}^{2} / \mathrm{s}\right)\end{array}$} & $\leq 2.25$ & 20 & 12 \\
\hline & $>2.25$ & 2 & 3 \\
\hline \multicolumn{2}{|l|}{ Sensitivity } & \multicolumn{2}{|l|}{$90.91 \%$} \\
\hline \multicolumn{2}{|l|}{ Specificity } & \multicolumn{2}{|l|}{$20 \%$} \\
\hline \multicolumn{2}{|c|}{ Positive Predictive Value } & \multicolumn{2}{|l|}{$62.5 \%$} \\
\hline \multicolumn{2}{|c|}{ Negative Predictive Value } & \multicolumn{2}{|l|}{$60 \%$} \\
\hline \multicolumn{2}{|c|}{ Accuracy } & \multicolumn{2}{|l|}{$62.16 \%$} \\
\hline \multicolumn{2}{|l|}{ Youden's index } & \multicolumn{2}{|l|}{0.11} \\
\hline \multicolumn{2}{|l|}{ Area under curve } & \multicolumn{2}{|l|}{0.861} \\
\hline \multicolumn{2}{|c|}{ Standard error of mean } & \multicolumn{2}{|l|}{0.066} \\
\hline \multicolumn{2}{|c|}{$95 \% \mathrm{Cl}$} & \multicolumn{2}{|l|}{$0.731-0.99$} \\
\hline \multicolumn{4}{|l|}{$P$-value $<0.000$} \\
\hline
\end{tabular}




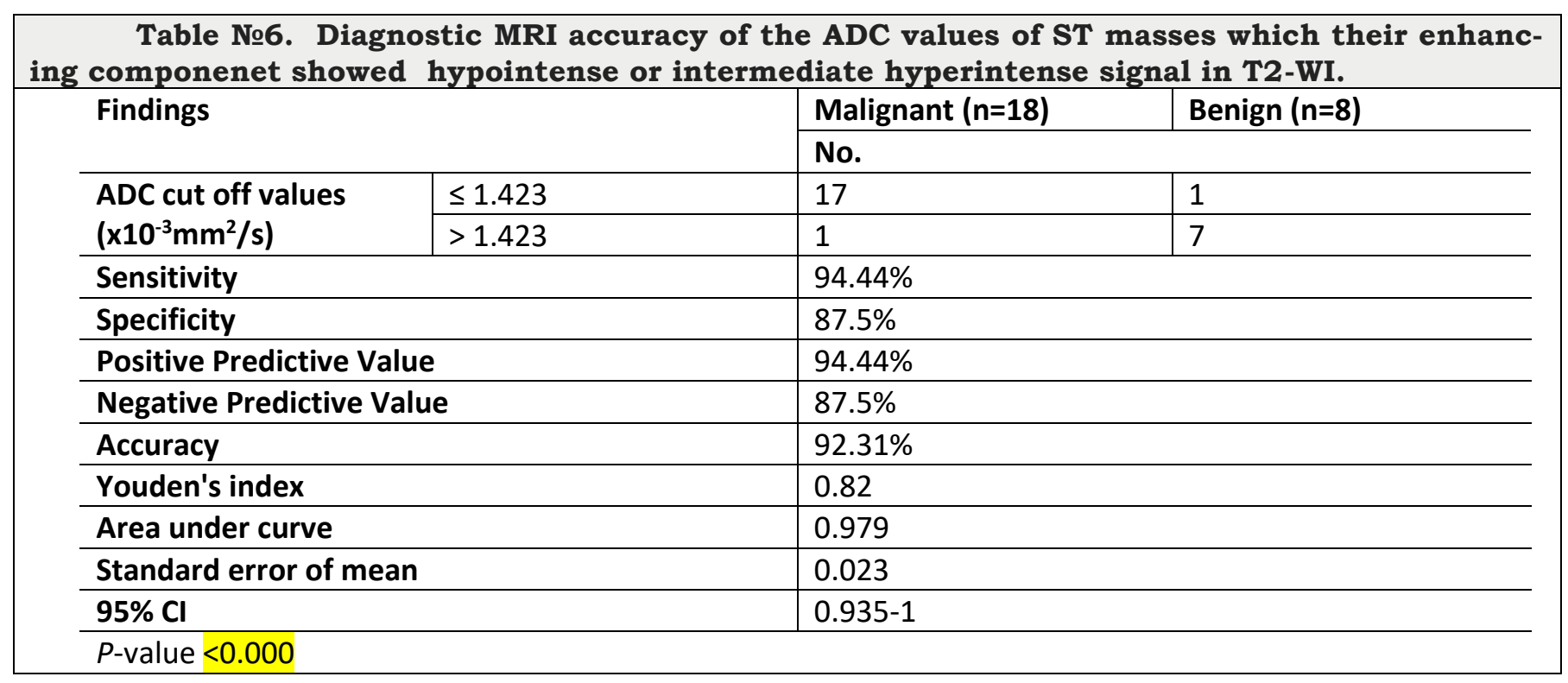

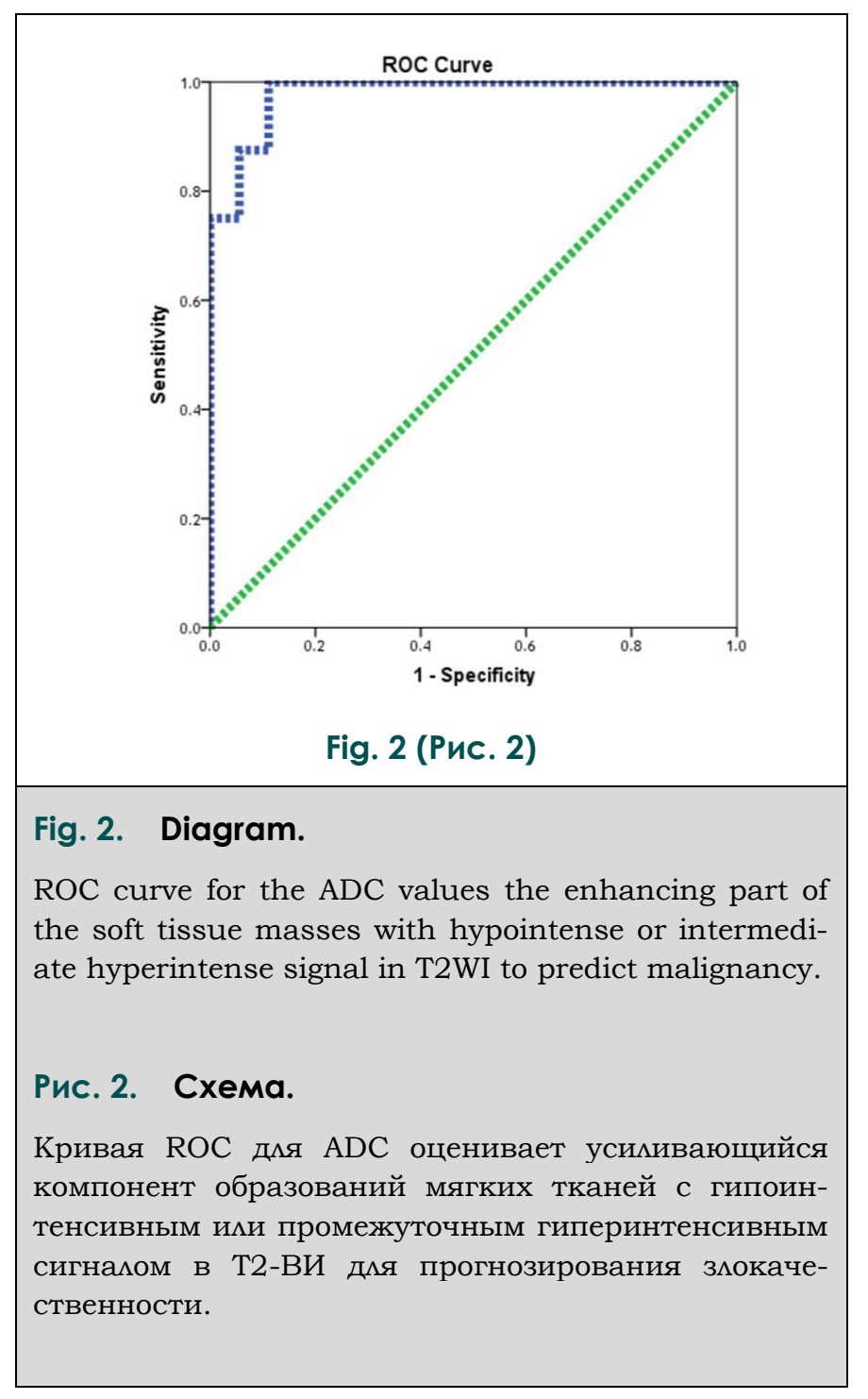

off value was $\leq 2.25 \times 10-3 \mathrm{~mm} 2 / \mathrm{s}$ for malignant STTs as whole, with a high sensitivity of $90.91 \%$, a low specificity of $20 \%$, PPV was $62.5 \%$, and NPV was $60 \%$. Accuracy was $62.16 \%$, the Youden's index was calculated 0.11 , which indicated that there might be a false positive or false negative

which was statistically significant $(\mathrm{P}$-value $<0.000)$ for the diagnosis of malignant STTs. The ROC curve was obtained by plotting ADC variables at different cut-off values. SPSS software was used to estimate the area under the curve (AUC), was (0.861; $\mathrm{SE}=0.066 ; 95 \% \mathrm{CI}=0.731-0.99)$, as shown in Table 5 (Fig. 5).

Particularly, the ADC cut off value was $\leq 1.42 \times 10-3 \mathrm{~mm} 2 / \mathrm{s}$ for malignant soft tissue masses with low signal or intermediate hyperintensity signal of the enhancing part in T2-WI, with a high sensitivity of $94.44 \%$, a high specificity of $87.5 \%$, PPV was $94.44 \%$, and NPV was $87.5 \%$. Accuracy was $92.31 \%$. The Youden's index was calculated 0.82 , which indicated that there were no false positive or false negative results. These were statistically significant association (P-value $<0.000)$ for the diagnosis of malignant soft tissue masses. The ROC curve was obtained and the AUC, was (0.979; $\mathrm{SE}=0.023 ; 95 \% \mathrm{CI}=0.935-1)$, as shown in Table 6 (Fig. 6).

Discussion.

MRI is the modality of choice for evaluating soft tissue masses regarding diagnosis, characterization and planning for effective tumor management [10]. DWI is a functional MRI technique and can be incorporated into routine MRI protocols with little additional scanning time, resulting in a non-invasive method for the evaluation of STTs based on their histological composition [11].

The lower limbs represented the common 


\section{RUSSIAN ELECTRONIC JOURNAL OF RADIOLOGY}

site of STTs in this study. In Romeih et al. study reported 30 patients had lower limb soft tissue lesions, while other lesions were detected in the upper limbs and trunk [12].

The benign STTs recorded in $40.5 \%$, while malignant tumors were found in $59.5 \%$ of patients. That is agreement with the results of Romeih et al. (benign 44\% vs. malignant 56\%), but disagree with Chung et al., as 102 lesions were malignant and 164 were benign, and Lee et al., as 66 lesions were non-malignant and 29 were malignant [12, 13, 14].

In reviewing previous studies, we found the evaluation of MR images by experienced radiologists with a centralized approach has been found to yield better diagnoses of soft-tissue tumours. Since most of soft tissue tumors are T1-isointense or hypointense and T2-hyperintense in signal intensity. The presence of T1-hyperintensity or T2hypointensity in soft tissue tumors is occasionally found and helpful in differential diagnosis when present [7-9, 15-20, 21]. An intratumoral T1hyperintensity is suggestive of fat, subacute hemorrhage, high proteinaceous fluid, or melanin. Fat-suppression techniques are helpful to distinguish fat from the other T1-hyperintense materials. T2-hypointense substances include calcifications/ossifications, hemorrhages, vascular signal voids, or collagenous tissues. The T2-hypointense element can be a clue of some benign soft tissue tumors such as tenosynovial giant cell tumor, fibromatosis, and desmoplastic fibroblastoma [16, 21].

DW-MRI with ADC mapping is a rapidly, valuable, non-invasive, non-contrast tool for reliably differentiating between benign and malignant STTs [12].

In a meta-analysis study conducted by Zou et al., patients with malignant STTs have low ADC values measurements with DWI as compared to benign. Consequently, ADC measurements with DWI may be reliable imaging techniques in differential diagnosis of soft tissue tumor [11].

In this study, we calculated ADC values for benign and malignant masses. Regarding benign, it was $(1.97 \times 10-3 \mathrm{~mm} 2 / \mathrm{s} \pm 0.39)$ for hemangiomas which was highest among other masses, (1.62x10$3 \mathrm{~mm} 2 / \mathrm{s} \pm 0.256)$ for benign neurogenic tumors, $(1.54 \times 10-3 \mathrm{~mm} 2 / \mathrm{s} \pm 0.014)$ for fibromatosis. While in malignant masses, the myxoid liposarcoma was the greatest ADC with $(2.11 \times 10-3 \mathrm{~mm} 2 / \mathrm{s} \pm 0.45)$, followed by MPNST with $(1.23 \times 10-3 \mathrm{~mm} 2 / \mathrm{s}$ \pm 0.26 ), whereas lowest ADC value were found NHL and extramedullary plasmacytoma $(0.545 \times 10-3$ $\mathrm{mm} 2 / \mathrm{s} \pm 0.035)$ with a case of myeloid sarcoma $(0.48 \times 10-3 \mathrm{~mm} 2 / \mathrm{s})$, and all these masses are related to hematological disease.

Almost always all pervious researchers showed different recordings in their published pa- per, like study of Hassanien et al., they mentioned that the highest ADC value for malignant STTs seen in high-grade myxofibrosarcoma $(2.02 \times 10-3$ $\mathrm{mm} 2 / \mathrm{s})$ and synovial sarcoma $(1.02 \times 10-3$ $\mathrm{mm} 2 / \mathrm{s})$, while the lowest ADC value was seen in undifferentiated round cell sarcoma $(0.53 \times 10-3 \mathrm{~mm} 2 / \mathrm{s})$, and nearly all malignant soft tissue neoplasms (except for high-grade myxofibrosarcoma) have ADC values less than $1.1 \times 10-3 \mathrm{~mm} 2 / \mathrm{s}$. They calculated the mean ADC value of benign and malignant soft tissue tumors was $1.53 \pm 0.91 \times 10-3 \mathrm{~mm} 2 / \mathrm{s}$ and $0.84 \pm 0.33$ $\mathrm{x} 10-3 \mathrm{~mm} 2 / \mathrm{s}$, respectively [22]. Regarding the benign tumors, the greatest ADC value was seen in case of hemangioma $(2.65 \times 10-3 \mathrm{~mm} 2 / \mathrm{s})$ and cavernous hemangiomas $(2.5 \times 10-3 \mathrm{~mm} 2 / \mathrm{s})$ while the lowest one was seen in lipoma $(0.3 \times 10-3 \mathrm{~mm} 2 / \mathrm{s})[22]$.

Other study done by Romeih et al., they reported that the most common malignant lesion was rhabdomyosarcoma with low ADC values with a mean of $0.78 \pm 0.25 \times 10-3 \mathrm{~mm} 2 / \mathrm{s}$. they found six cases of synovial sarcoma (the second-most common malignant lesions) a mean ADC value of $0.77 \pm 0.21 \times 10-3 \mathrm{~mm} 2 / \mathrm{s}$. also they included four cases of liposarcoma, and two cases each of undifferentiated round-cell sarcoma, Ewing's sarcoma and fibrosarcoma (ADC values of 0.53, 0.80, and $0.70 \times 10-3 \mathrm{~mm} 2 / \mathrm{s}$, respectively) [12]. Also, they encountered four cases of malignant myxoid tumours (myxoid liposarcoma) with high ADC values of $2.30 \pm 0.28 \times 10-3 \mathrm{~mm} 2 / \mathrm{s}$ [12]. They observed the highest ADC values in giant-cell tumours $(2.35 \times 10-3 \mathrm{~mm} 2 / \mathrm{s})$, haemangiomas $(2.10 \times 10-3$ $\mathrm{mm} 2 / \mathrm{s})$, and schwannomas $(1.9 \times 10-3 \mathrm{~mm} 2 / \mathrm{s})$ [12]. Our findings are consistent with those reported by Costa, who found high ADC values in haemangiomas $(2.3 \times 10-3 \mathrm{~mm} 2 / \mathrm{s})$, but they reported that (fibromatosis and neurofibroma) had low ADC values $(1.1 \times 10-3 \mathrm{~mm} 2 / \mathrm{s}$ and $1.35 \times 10-3$ $\mathrm{mm} 2 / \mathrm{s}$, respectively) [23].

Nagata et al. found that myxoid-containing and non-myxoid tumours had ADC values of 1.92 $\pm 0.41 \times 10-3 \mathrm{~mm} 2 / \mathrm{s}$ and $0.97 \pm 0.33 \times 1010-3$ $\mathrm{mm} 2 / \mathrm{s}$, respectively $(\mathrm{P}<0.01)$. Also they found that liposarcoma, Ewing's sarcoma and fibrosarcoma had ADC values of $1.20 \pm 0.04,0.83 \pm 0.09$, and $0.92 \pm 0.07 \times 1010-3 \mathrm{~mm} 2 / \mathrm{s}$, respectively. They stated that ADC values of, cystic, cartilaginous and myxomatous components tend to be higher than those of other neoplasms and even ADC values of malignant cartilaginous tumor may be higher than those of benign neoplasms [24].

The most common cause of increased diffusion in myxoid-containing tumors is the abundance of free water in the myxoid matrix, which lead to highest ADC values, directly reflecting the low collagen and high mucin content of these lesions as well as the large amount of extracellular 


\section{RUSSIAN ELECTRONIC JOURNAL OF RADIOLOGY}

water seen histologically [25]. ADC values are relatively low in several non-myxoid malignant tumours, such as undifferentiated high-grade pleomorphic sarcoma, Ewing's sarcoma, malignant peripheral nerve sheath tumours, and lymphoma [26]. In contrast, myxoid-containing tumours, whether benign or malignant, exhibit significantly higher ADC values than non-myxoid tumours [25, 26].

Generally, the mean of ADC value was higher in benign STTs than that in malignant STTs $(1.84 \pm 0.37$ vs. $1.09 \pm 0.58)$, and it was strongly statistically significant difference (Paired T-test= 6.031, 95\%CI $=1.211-5.756$, P-value $<0.000$ ). These findings agree with findings of Romeih et al. study, and Hassanien et al. study $[12,27]$. Romeih et al. reported that the mean ADC values of malignant STTs were significantly lower than those of benign STTs. They found the mean ADC value of benign STTs was $1.43 \pm 0.56 \times 10-3$ $\mathrm{mm} 2 / \mathrm{s}$, while that of malignant STTs was $0.74 \pm$ $0.18 \times 10-3 \mathrm{~mm} 2 / \mathrm{s}$; these values were significantly different $(\mathrm{P}<.001)$ [12].

The studies made by Van Rijswijk, Neubauer et al., Zou et al., Grande et al., Nagata et al., Maeda et al., Jeon et al., and Song et al. also supported our data $[9,11,17,23,24,27,28]$.

In our study \, we further subdivided the soft tissue masses into two groups according to the T2 signal intensity of the enhancing componenet and re measured the mean ADC value for each group and we found that: The mean ADC value for the malignant masses which their enhancing part expressed very hyperintense signal in T2-WI was higher than that of benign (2.11 \pm 0.45 vs. $2.03 \pm 0.39)$, and the same thing for cut off value (3.1 vs. 2.8), with no significant association $(\mathrm{P}=0.49)$, this group of masses included hemangiomas and tumors with myxomatous component (whether malignant as myxoid liposarcoma or benign as intramuscular myxoma), while the mean ADC value for the malignant masses with the enhancing solid component were of low signal or intermediate hyperintense signal in T2-WI was lower than the mean of benign $(0.863 \pm 0.28$ vs. $1.675 \pm 0.39$ ), with statistically significant association $(\mathrm{P}=0.002)$, which can be helpful in differentiated between malignant from benign masses in this group of masses.

In DW-MRI, malignant STTs showed high signal intensity than benign STTs, with the ADC cut off value was $\leq 2.25 \times 10-3 \mathrm{~mm} 2 / \mathrm{s}$, which have high sensitivity, and low specificity with accuracy reached to $62.16 \%$, those were statistically significant $(\mathrm{P}<0.000)$. Here, the area under the curve (AUC), was $0.852 \quad(\mathrm{SE}=0.067 ; 95 \% \mathrm{CI}=0.721-$ 0.983). Similarly, Neubauer et al. reported an area under the ROC curve of 0.89 with the same sensitivity of $90 \%$, but a high specificity of $91 \%$ [26].
Whereas our results were higher than that of Romeih et al. study, since they obtained the following values: area under the ROC curve $=0.829$ ( $\mathrm{SE}=0.084 ; 95 \%$ CI $0.82-1.03$ ), a sensitivity of $83.3 \%$, a specificity of $72.7 \%$ (higher than we obtained); $(\mathrm{P}<0.001)$, and a PPV and NPP of $80 \%$ [12].

In practical manner, the ADC cut off value was $\leq 1.42 \times 10-3 \mathrm{~mm} 2 / \mathrm{s}$ for malignant soft tissue masses with low signal or intermediate hyperintensity signal of the enhancing part in T2-WI, with a high sensitivity of $94.44 \%$, a high specificity of $87.5 \%$, and accuracy was reached to $92.31 \%$, with statistically significant association (P-value $<0.000$ ).

ADC values are comparatively low in several non-myxoid malignant tumors such as malignant peripheral nerve sheath tumor, lymphoma, undifferentiated high-grade pleomorphic sarcoma and Ewing sarcoma. The pathologic outcomes of such tumors reveal hypercellularity. In contrast, myxoid-containing tumors, either benign or malignant, showed significant values of ADC higher than non-myxoid tumors [19, 26, 29].

In Hassanien et al. study, the mean ADC value of benign was significantly higher than that of malignant soft tissue tumors, and the ROC curve showed: confidence interval (95\% CI: 0.5100.932 and AUC: 0.721) [22]. The study had obtained threshold value $1.235 \times 10-3 \mathrm{~mm} 2 / \mathrm{s}$ with $73 \%$ sensitivity (lower than we obtained) and 91.7\% specificity (higher than we obtained), where there was a high significant difference between malignant and benign soft tissue neoplasms [22].

By conclusion, Hassanien et al. said that supplement of DWI with quantitative ADC mapping to the routine MR examination is of great value as non-invasive tool in discrimination between benign and malignant soft tissue neoplasm especially in the inconclusive cases and in differentiation between myxoid tumors from cystic lesions [22].

Pekcevik et al. concluded that the preliminary results showed that ADC values are significantly higher in benign tumors. Although there was some overlap between benign and malignant tumors, adding DWI MRI to routine soft tis $\neg$ sue tumor protocols may improve diagnostic accuracy [20].

Subhawong et al. in their study, stated that use of a mean value for ADC more than $(2.5 \times 10-3 \mathrm{~mm} 2 / \mathrm{s})$ yielded a $(80 \%$ and $100 \%)$ sensitivity and a specificity respectively in diagnosis of cysts and benign cystic lesions. ADC mapping may be particularly helpful in suggesting the true neoplastic nature of tumors, such as myxomas, that mimic cysts by displaying homogeneous T2hyperintensity as they have high ADC value but less than $(2.5 \times 10-3 \mathrm{~mm} 2 / \mathrm{s})[19]$. 


\section{RUSSIAN ELECTRONIC JOURNAL OF RADIOLOGY}

\section{Conclusions.}

In a selected group of soft tissue masses which their enhancing componenet express low or intermediate hyperintense signal in $\mathrm{T} 2$-WI, the mean ADC value was lower in malignant soft tissue masses than that in benign masses with a cut off value of $1.42 \times 10-3 \mathrm{~mm} 2 / \mathrm{s}$ gives a high sensi-

\section{References:}

1. Enzinger F, Weiss S. Soft Tissue Tumors. 2nd ed. St. Louis: Mosby. 1988; PP. 1-18.

2. Grainger G, Adam A, Dixon A et al, Grainger and Allison's Diagnostic Radiology: A text book of medical imaging 6 th edition 2015

3. Wu JS, Hochman MG. Soft-tissue tumors and tumor like lesions: a systematic imaging approach. Radiology. 2009; 253 (2): 297-316.

4. Benedikt RA, Jelinek JS, Kransdorf MJ, Moser RP, Berrey BH. $M R$ imaging of soft tissue masses: role of gadopentetate dimeglumine. J Magn Reson Imaging. 1994; 4 (3): 485-90.

5. van Rijswijk CS, Geirnaerdt MJ, Hogendoorn PC, Taminiau $A H$, van Coevorden $F, Z$ winderman $A H$, et al. Soft tissue tumors: value of static and dynamic gadopentetate dimeglumineenhanced MR imaging in prediction of malignancy. Radiology. 2004; 233 (2): 493-502.

6. Vilanova JC, Baleato A, Balliu E. Muscoloskeletal Application of DWI. In: Luna A, Ribes R, Soto JA, editors. In diffusion MRI outside the brain. Heidelber Springer. 2012; PP. 339-64.

7. Mirowitz SA, Totty WG, Lee JK. Characterization of musculoskeletal masses using dynamic Gd-DPTA enhanced spin-echo MRI. J Comput Assist Tomogr. 1992; 16 (1): 120-5.

8. Van Rijswijk CS, Kunz P, Hogendoorn PC, Taminiau AH, Doornbos J, Bloem JL. Diffusion-Weigthe MRI in the characterization of soft tissue tumors. J Magn Reson Imaging. 2002; 15 (3): 302-7.

9. Benassi MS, Rimondi E, Balladelli A, Ghinelli C, Magagnoli G, Vanel $D$. The role of imaging for translational research in bone tumors. Eur J Radiol. 2011; 82 (12): 2115-23.

10. Ahlawat SH, Fayad LM. De novo assessment of pediatric musculoskeletal soft tissue tumors: beyond anatomic imaging. Pediatrics. 2015; 136 (1): 194-201.

11. Zou Y, Wang QD, Zong M, Zou YF, Shi HB. Apparent diffusion coefficient measurements with diffusion-weighted imaging for differential diagnosis of soft-tissue tumor. $J$ Can Res Ther. 2016; 12: 864-70.

12. Romeih $M$, Raafat $T$, Khalaf $M$, Sallam $K$. The diagnostic value of diffusion-weighted magnetic resonance imaging in characterization of musculoskeletal soft tissue tumors. Egypt $J$ Radiol Nucl Med. 2018; 49: 400-407.

13. Chung WJ, Chung HW, Shin MJ, Lee SH, Lee MH, Lee JS, Kim MJ, Lee WK. MRI to differentiate benign from malignant soft-tissue tumours of the extremities: a simplified systematic imaging approach using depth, size and heterogeneity of signal intensity. Br J Radiol. 2012; 85 (1018): e831-6.

14.Lee JH, Kim HS, Yoon YC, et al. Characterization of small, deeply located soft-tissue tumors: Conventional magnetic resonance imaging features and apparent diffusion coefficient for differentiation between non-malignancy and malignancy. PLoS One. 2020; 15 (5): e0232622. tivity and a high specificity.

Authors contributions.

All authors equally contributed to Conceptualization; Data curation; Formal analysis; Investigation; Methodology; Resources; Software; Visualization; Roles/Writing - original draft; Writing review \& editing.

15. Liu L, Wu N, Ouyang H. Diagnostic value of delineating deep fascia in distinguishing between benign and malignant softtissue tumors in lower limbs using 3.0 T magnetic resonance imaging. J Magn Reson Imaging. 2011; 33 (1): 173-9.

16. Gielen JL, De Schepper AM, Vanhoenacker F, Parizel PM, Wang XL, Sciot R, et al. Accuracy of MRI in characterization of soft tissue tumors and tumor-like lesions. A prospective study in 548 patients. Eur Radiol. 2004; 14: 2320-2330.

17. Jeon JY, Chung HW, Lee MH, Lee SH, Shin MJ. Usefulness of diffusion-weighted MR imaging for differentiating between benign and malignant superficial soft tissue tumours and tumour-like lesions. Br J Radiol. 2016; 89: 20150929.

18. Song Y, Yoon YC, Chong Y, Seo SW, Choi YL, Sohn I, et al. Diagnostic performance of conventional MRI parameters and apparent diffusion coefficient values in differentiating between benign and malignant soft-tissue tumours. Clin Radiol. 2017; 72: 691 e691-691 e610.

19. Subhawong TK, Jacobs MA, Fayad LM. Insights into quantitative diffusion-weighted MRI for musculoskeletal tumour imaging. AJR. 2014; 203: 560-572.

20. Pekcevik Y, Kahya MO, Kaya A. Characterization of Soft Tissue Tumors by Diffusion-Weighted Imaging. Iran $J$ Radiol. 2015; 12 (3): e15478.

21. Kang HS et al. Oncologic Imaging: Soft Tissue Tumors. 2017; 10. 100/978-981-287-718-5_17

22.Hassanien OA, Younes RL, Dawoud RM. Diffusion weighted MRI of soft tissue masses: Can measurement of ADC value help in the differentiation between benign and malignant lesions? The Egyptian Journal of Radiology and Nuclear Medicine. 2018; 49: 681-688.

23. Battal B, Akg"un V, Kocao glu M. Diffusion weighted MRI beyond the central nervous system in children. Diagn Interv Radiol. 2012; 18: 288-97.

24. Bancroft LW, Kransdorf MJ, Peterson JJ, O'Connor MI. Benign fatty tumors: classification, clinical course, imaging appearance, and treatment. Skeletal Radiol. 2006; 35: 719-733.

25. Subhawong TK, Fishman EK, Swart JE, Carrino JA, Attar S, Fayad LM. Soft-tissue masses and masslike conditions:what does CT add to diagnosis and management?AJR Am J Roentgenol. 2010; 194 (6): 1559-67.

26. Neubauer $H$, et al. Diffusion-weighted MRI for detection and differentiation of musculoskeletal tumorous and tumor-like lesions in pediatric patients. World $J$ Pediatr November. 2012; 8 (4): 342-9.

27. Grande FD, Subhawong T, et al. Detection of soft-tissue sarcoma recurrence: added value of functional MR imaging techniques at 3.0 T1. Radiology. 2014; 271 (2): 499-511.

28. Costa FM, Ferreira EC, Vianna EM. Diffusion-weighted magnetic resonance imaging for the evaluation of musculoskeletal tumors. Magn Reson Imaging Clin N Am. 2011; 19 (1): 159-80. 


\section{RUSSIAN ELECTRONIC JOURNAL OF RADIOLOGY}

29. Lee SY, Jee WH, Jung JY, Park MY, Kim SK, Jung CK, et al. Differentiation of malignant from benign soft tissue tumours: use of additive qualitative and quantitative diffusion-weighted $M R$ imaging to standard MR imaging at 3.0 T. Eur Radiol. 2016; 26: 743-754. 